\title{
Food source of intertidal nematodes in the Bay of Marennes- Oléron (France), as determined by dual stable isotope analysis
}

\author{
P. Riera ${ }^{1}$, P. Richard ${ }^{1, *}$, A. Grémare ${ }^{2}$, G. Blanchard ${ }^{1}$ \\ 'CREMA L'Houmeau CNRS-IFREMER, UMR 10, BP 5, Place du Séminaire, F-17137 L'Houmeau, France \\ ${ }^{2}$ Observatoire Océanologique de Banyuls-sur-Mer, Université Pierre et Marie Curie, URA CNRS no. 117, BP 44, F-66650 Banyuls-sur-Mer, France
}

\begin{abstract}
Nematodes living on an intertidal mudflat of the Marennes-Oléron Bay (France) were assayed for $\delta^{13} \mathrm{C}$ and $\delta^{15} \mathrm{~N}$ ratios together with their potential food resources between July 1992 and May 1993. Results suggest that nematodes do not exploit all the components of the sedimented organic matter (SOM) pool at the same rate. Furthermore, based on coefficients of average trophic enrichment found in the literature for both $\mathrm{C}$ and $\mathrm{N}$, the enrichment of nematodes in ${ }^{13} \mathrm{C}$ and their depletion in ${ }^{15} \mathrm{~N}$ relative to SOM suggest that microphytobenthos constitutes their main food source in this particular environment.
\end{abstract}

KEY WORDS: Nematodes - Microphytobenthos - Food sources $\cdot$ Stable isotope ratios

A key role in the transfer of organic matter within benthic food webs is generally attributed to meiofauna due to its intermediary trophic position (Coull \& Bell 1979). However, in spite of their numerical importance in estuarine environments, resource partitioning by meiofaunal communities is not yet clearly understood. Meiobenthic fauna mainly consists of grazers adapted to ingestion of specific microbial food items such as bacteria and microalgae (Gerlach 1978, Incze et al. 1982, Colijn \& de Jonge 1984). The ingestion experiments that have been conducted to quantify the relative importance of these 2 kinds of prey have shown that meiofauna have a significant impact on microbially mediated processes (Montagna 1995). Differences among sites reflect not only differences in the methods that were used but also the complexity of feeding strategies of meiobenthos subjected to diverse sets of ecological conditions (Brown \& Sibert 1977. Montagna 1984, Montagna \& Bauer 1988, Montagna \& Yoon 1991). Moreover, these studies were focused only on ingestion, and thus could not account for differ-

•E-mail: prichard@ifremer.fr ences in the absorption and the actual assimilation of these 2 food sources (Montagna 1984).

The use of natural stable isotope analysis may overcome these difficulties, because it provides insights on the sources of organic matter that are actually assimilated over a long period of time. This approach is based on the close relationship between the stable isotope composition of a consumer and its food (Fry \& Sherr 1984). However, determination of food sources using solely carbon isotope composition is often equivocal (Haines \& Montague 1979, Currin et al. 1995) and a dual isotope approach, for example carbon and nitrogen, may be easier to interpret (Fry 1988). Despite its potential, the application of the stable isotope technique to meiofauna in coastal environments has been restricted to a few studies (Schwinghamer et al. 1983, Couch 1989). Such a restriction mainly resulted from methodological constraints (i.e. the need for large amounts of living and debris-free organisms for isotope analysis).

Within many coastal environments where detritus from the C4 angiosperm Spartina is a large contributor to the sediment organic matter (SOM) pool, the importance of microphytobenthos as a food source for meiofauna could not be clearly established by stable isotope analysis, because carbon and nitrogen isotopic compositions of benthic diatoms and detritus-inhabiting bacteria largely overlap (Schwinghamer et al. 1983, Couch 1989). In contrast to the eastern coast of the United States, where Spartina marshes dominate, the mudflats in the Marennes-Oléron Bay, France, are entirely bare and almost completely free of $\mathrm{C} 4$ plants (Riera 1995), and the main primary producer is the microphytobenthos (Cariou-Le Gall \& Blanchard 1995). The interpretation of isotopic data for the purpose of determining the origin of the organic matter sustaining the benthic food web may thus be easier in this particular 


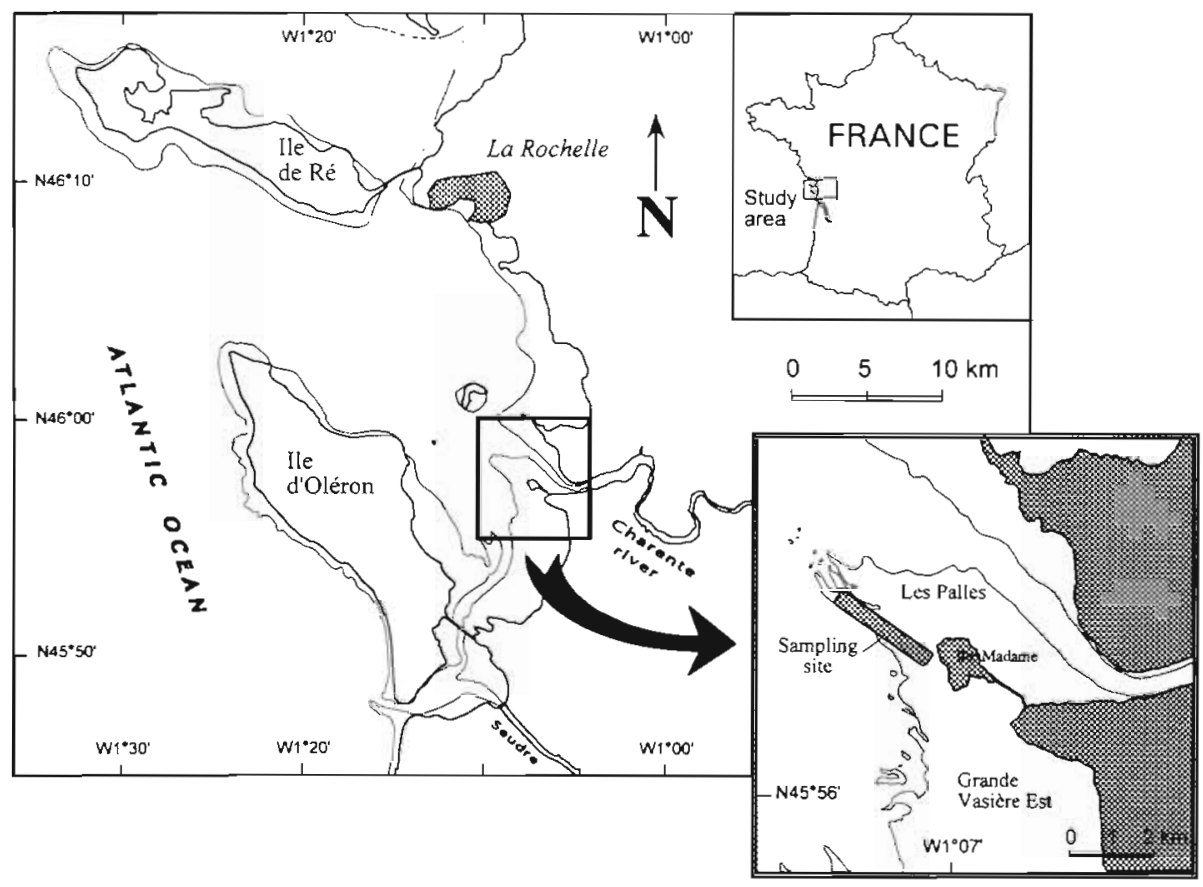

Fig. 1. Sampling area in Marennes-Oléron Bay (France). (-) Limit of the intertidal mud flats environment. The aim of the present study was to assess the main food sources of benthic nematodes on the intertidal mudflats of the Marennes-Oléron Bay by comparing their stable isotope composition $\left(\delta^{13} \mathrm{C}\right.$ and $\delta^{15} \mathrm{~N}$ ) with that of their potential food resources at different periods of the year.

Material and methods. The Marennes-Oléron Bay: The estuarine bay of Marennes-Oléron is located on the central Atlantic coast of France (Fig. 1). It is protected by 2 large islands: the lle de Ré to the north and the lle d'Oléron to the west. A complete description of the bay has been provided elsewhere (Riera \& Richard 1996). It is shallow (average depth of $4 \mathrm{~m}$ ), with strong currents (sometimes $>1 \mathrm{~m} \mathrm{~s}^{-1}$ ), and a $6 \mathrm{~m}$ tidal range. All these characteristics generate well-mixed and highly turbid waters. Intertidal mudflats account for more than half of the total surface area of the bay at spring low tides. These flats are characterized by a high

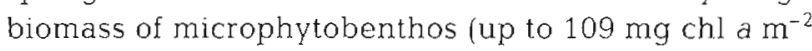
within the first $\mathrm{cm}$, P. Riera unpubl.). Nematodes represent the dominant meiofaunal group $185 \%$ in number of individuals), followed by harpacticoid copepods $(14 \%)$ and a few ostracods (Montagna et al. 1995). Charente River inflow carries inputs of detrital organic matter and nutrients that support the main part of the phytoplanktonic production within the Bay. Phytoplankton production, however, is limited by the high turbidity (Ravail-Legrand 1993). Macroalgae are present only as small patches associated with rocky reefs representing less than $0.05 \mathrm{~km}^{2}$ over the $200 \mathrm{~km}^{2}$ of the whole bay (Callens 1994). At the sampling site ('Les Palles'), 3 genera are present (Fucus, Enteromorpha and Ulva), but Fucus constitutes almost all of the macroalgal biomass

Sample collection and preparation: All samples were collected on an intertidal mudflat located just south of the mouth of the Charente River (Fig. 1). Samples were collected seasonally from July 1992 to May 1993 (i.e. twice in summer, autumn and winter, and once in spring) to assess temporal changes of the isotopic compositions.

Water samples (20 1) were collected at high tide $( \pm 1 \mathrm{~h}$ ) by pumping from a depth of about $50 \mathrm{~cm}$ below the water surface. Particulate organic matter (POM) for isotope analyses was obtained within $2 \mathrm{~h}$ after collection by filtration on precombusted Whatman GF/F glass fiber filters. The membranes were then acidified $(1 \mathrm{M} \mathrm{HCl})$ to remove carbonates, quickly rinsed with Milli-Q water, freeze-dried and kept frozen $\left(-80^{\circ} \mathrm{C}\right)$ until analysis.

Sediment samples were taken at low tide by scraping the upper $1 \mathrm{~cm}$ of mud and were taken to the laboratory within 1 h. Samples were then homogenized with a spatula. A subsample of approximately $5 \mathrm{~g}$ was used for the analysis of sediment organic matter (SOM). It was freeze-dried, and ground using a mortar and pestle. Then, $200 \mathrm{mg}$ was acidified with $1 \mathrm{M} \mathrm{HCl}$ to remove inorganic carbon. In order to prevent any loss of dissolved organics, these samples were not rinsed They were dried overnight at $50^{\circ} \mathrm{C}$ under a fume extractor to evaporate the acid. Once dried, the sediment was mixed with Milli-Q water, freeze-dried, ground again to a fine powder and kept frozen $\left(-80^{\circ} \mathrm{C}\right)$ until analysis 
Table 1. Mean $\delta^{13} \mathrm{C}$ and $\delta^{15} \mathrm{~N}$ values (\% $\%$ SD) for nematodes, SOM, suspended POM, and potential food sources for the different seasons from July 1992 to May 1993. The number of analyzed samples is shown in parentheses. (-) Not sampled

\begin{tabular}{|c|c|c|c|c|c|c|c|c|}
\hline \multirow{2}{*}{ Sample } & \multicolumn{2}{|c|}{ Summer 1992} & \multicolumn{2}{|c|}{ Autumn 1992} & \multicolumn{2}{|c|}{ Winter 1993} & \multicolumn{2}{|c|}{ Sprung 1993} \\
\hline & $\delta^{13} \mathrm{C}$ & $\delta^{15} N$ & $\delta^{13} \mathrm{C}$ & $\delta^{1} \mathrm{~N}$ & $\delta^{12} \mathrm{C}$ & $\delta^{15} \mathrm{~N}$ & $\delta^{17} \mathrm{C}$ & $\delta^{15} \mathrm{~N}$ \\
\hline Nematodes & $\begin{array}{c}-16.4=0.8 \\
\text { (7) }\end{array}$ & $\begin{array}{c}8.9 \pm 1.0 \\
(3)\end{array}$ & $\begin{array}{c}-15.9 \pm 0.7 \\
(5)\end{array}$ & $\begin{array}{c}9.3 \pm 0.8 \\
(5)\end{array}$ & $\begin{array}{c}-16.2 \pm 1.2 \\
\text { (3) }\end{array}$ & - & $\begin{array}{c}-15.3 \pm 0.9 \\
\text { (2) }\end{array}$ & $\begin{array}{c}9.0 \pm 0.3 \\
(2)\end{array}$ \\
\hline SOM & $\begin{array}{c}-19.3 \pm 0.9 \\
(6)\end{array}$ & $\begin{array}{c}6.6 \pm 0.2 \\
(2)\end{array}$ & $\begin{array}{c}-19.0 \pm 0.6 \\
{[6]}\end{array}$ & - & $\begin{array}{c}-18.7 \pm 1.6 \\
(5)\end{array}$ & $\begin{array}{c}6.3 \pm 0.0 \\
(2)\end{array}$ & $\begin{array}{c}-20.7 \pm 1.5 \\
\text { (3) }\end{array}$ & - \\
\hline Suspended POM & $\begin{array}{c}-22.9 \pm 0.5 \\
\text { (2) }\end{array}$ & $\begin{array}{c}6.5 \pm 0.7 \\
\text { (2) }\end{array}$ & $\begin{array}{c}-23.1 \pm 0.0 \\
(2)\end{array}$ & - & $\begin{array}{c}-22.7 \pm 0.6 \\
(6)\end{array}$ & $\begin{array}{l}6.1 \\
(1)\end{array}$ & $\begin{array}{c}-22.5 \pm 0.6 \\
\text { (4) }\end{array}$ & - \\
\hline Microphytobenthos & - & $\begin{array}{l}6.6 \\
(1)\end{array}$ & $\begin{array}{c}-15.6 \pm 0.3 \\
(2)\end{array}$ & - & $\begin{array}{c}-15.6 \pm 0.9 \\
(3)\end{array}$ & $\begin{array}{c}4.6 \pm 0.4 \\
\text { (3) }\end{array}$ & $\begin{array}{c}-16.9 \pm 0.6 \\
\text { (3) }\end{array}$ & $\begin{array}{c}5.9 \pm 0.2 \\
\text { (4) }\end{array}$ \\
\hline Fucus sp. & $\begin{array}{c}-18.6 \pm 0.7 \\
\text { (2) }\end{array}$ & $\begin{array}{c}9.2 \pm 0.6 \\
(2)\end{array}$ & $\begin{array}{c}-13.5 \pm 0.5 \\
\text { (2) }\end{array}$ & $\begin{array}{c}8.9 \pm 1.5 \\
(2)\end{array}$ & $\begin{array}{l}-15.9 \\
(1)\end{array}$ & $\begin{array}{l}8.0 \\
(1)\end{array}$ & $\begin{array}{c}-18.9 \pm 0.3 \\
\text { (3) }\end{array}$ & $\begin{array}{c}7.6 \pm 0.3 \\
\text { (3) }\end{array}$ \\
\hline Ulva sp. & $\begin{array}{c}-10.4 \pm 1.0 \\
\text { (4) }\end{array}$ & $\begin{array}{l}11.9 \\
(1)\end{array}$ & $\begin{array}{c}-9.8 \pm 0.2 \\
(2)\end{array}$ & $\begin{array}{c}10.8 \pm 1.1 \\
(3)\end{array}$ & $\begin{array}{c}-14.2 \\
\text { (1) }\end{array}$ & $\begin{array}{l}9.5 \\
(1)\end{array}$ & $\begin{array}{c}-10.0 \pm 0.3 \\
(4)\end{array}$ & $\begin{array}{l}8.6 \\
(1)\end{array}$ \\
\hline Enteromorpha sp. & $\begin{array}{c}-16.5 \pm 0.4 \\
\text { (3) }\end{array}$ & $\begin{array}{c}9.2 \pm 0.0 \\
(2)\end{array}$ & $\begin{array}{c}-17.0 \pm 1.2 \\
(2)\end{array}$ & $\begin{array}{c}12.0 \pm 0.5 \\
(2)\end{array}$ & - & - & $\begin{array}{c}-16.1 \\
(1)\end{array}$ & $\begin{array}{c}8.2 \pm 0.3 \\
(2)\end{array}$ \\
\hline
\end{tabular}

The rest of the sediment was used to isolate nematodes and benthic diatoms. Nematodes were extracted from 2 l of surficial sediment, using a method based on their downward migration under permanent light (Couch 1988). Although this method does not extract all nematodes, it is more satisfactory for stable isotope analysis than single density centrifugation using either sucrose or silica gel (Heip et al. 1974, de Jonge \& Bouwman 1977) because it does not add any interfering chemicals. After extraction, the nematodes were starved (12 h in $0.2 \mu \mathrm{m}$ filtered seawater) to clear gut contents, and rinsed before being manually cleaned of any remaining contaminants under the microscope. The method used to extract benthic diatoms was slightly modified from Couch (1989). The sediment was spread on flat trays to form a $1 \mathrm{~cm}$ thick layer and held under light. On the next day, when dense brown patches of benthic diatoms were visible, a nylon screen ( $63 \mu \mathrm{m}$ mesh) was laid upon the sediment surface and covered with a $5 \mathrm{~mm}$ thick layer of combusted silica powder $(60$ to $210 \mu \mathrm{m}$. Fluka Chemicals). The trays were illuminated 1 to $3 \mathrm{~h}$ more, the silica powder being kept moist by a slight spraying of filtered $(0.2 \mu \mathrm{m})$ seawater sampled at low tide from neighbouring tidal pools. The silica powder, into which the motile microalgae had migrated, was then gently scraped and sieved on a $63 \mu \mathrm{m}$ mesh to separate the diatoms from the largest part of the silica powder and from any nematodes or copepods present. All nematode and diatom samples were finally collected on previously combusted glass fiber filters, washed with $1 \mathrm{M} \mathrm{HCl}$, briefly rinsed with Milli-Q water, freeze-dried and kept frozen $\left(-80^{\circ} \mathrm{C}\right)$ until analysis.
Macroalgae were sampled at the rocky station of 'Les Palles' (Fig. 1). They were harvested manually, cleaned of their epibionts, washed with $1 \mathrm{M} \mathrm{HCl}$ to remove carbonates, rinsed with Milli-Q water and homogenized using a Polytron homogenizer. They were then freeze-dried, ground to a powder using a mortar and pestle and kept frozen $\left(-80^{\circ} \mathrm{C}\right)$ until analysis.

Stable isotope analysis: Samples for isotope analyses were prepared as in Boutton (1991). Before the purification of $\mathrm{CO}_{2}, \mathrm{~N}_{2}$ was trapped on silica gel granules in a stopcock sample ampule and analyzed immediately after $\mathrm{CO}_{2}$ collection (Mariotti 1982). The carbon and nitrogen isotope ratios were measured using a Sigma 200 (CJS Sciences, Winsford, England) double inlet, triple collector isotope ratio mass spectrometer. Data are expressed in the standard $\delta$ unit notation where $\delta X=\left[\left(R_{\text {sample }} / R_{\text {reference }}\right)-1\right] \times 10^{3}$, with $R={ }^{13} \mathrm{C} /{ }^{12} \mathrm{C}$ for carbon and ${ }^{15} \mathrm{~N} /{ }^{14} \mathrm{~N}$ for nitrogen, and reported relative to the Pee Dee Belemnite standard (PDB) for carbon and to air $\mathrm{N}_{2}$ for nitrogen. The typical precision of the overall procedure (i.e. preparation plus analysis) was $\pm 0.1 \%$ for carbon and $\pm 0.2 \%$ for nitrogen

Results. The average $\delta^{13} \mathrm{C}$ of microphytobenthos ranged from -16.9 (spring 1993) to $-15.6 \%$ (autumn 1992, winter 1993) (Table 1). There were no significant differences for $\delta^{13} \mathrm{C}$ of microphytobenthos among sampling periods (Kruskall-Wallis ANOVA, $p>0.1$ ). The corresponding $\delta^{15} \mathrm{~N}$ values were between 4.6 (winter 1993) and 6.6\% (summer 1992). The carbon data are very similar to existing values concerning benthic diatoms inhabiting salt marsh muddy sediments (Schwinghamer et al. 1983, Currin et al. 1995). Data concerning microalgal $\delta^{15} \mathrm{~N}$ are much scarcer in the 
literature. The results obtained in the present study are reasonably close to the $5.8 \%$ measured by Creach (1995) on the intertidal mudflat of the French Channel but higher than the $3.9 \%$ reported by Couch (1989) for the salt marshes of the southeastern coast of the United States.

The average $\delta^{13} \mathrm{C}$ of the 3 genera of macroalgae ranged from -18.9 (Fucus, spring 1993) to $-9.8 \%$ (Ulva, autumn 1992). The $\delta^{13} \mathrm{C}$ of the 3 macroalgae was not significantly different among the harvesting periods (Kruskal-Wallis ANOVA, $\mathrm{p}>0.4$ for Ulva and Enteromorpha and p $>0.1$ for Fucus), but Ulva carbon isotopic composition was much more enriched (from $-10.4 \%$ in summer 1992 to $-9.8 \%$ in autumn 1992) than that of the other macroalgae. Corresponding $\delta^{15} \mathrm{~N}$ was between 7.6 (Fucus, spring 1993) and 12.0\% (Enteromorpha, autumn 1992). That large range in $\delta^{13} \mathrm{C}$ values compared to the narrow range in $\delta^{15} \mathrm{~N}$ values is commonly found in the literature (see Currin et al. 1995).

The average $\delta^{13} \mathrm{C}$ of suspended POM near the mouth of the Charente Estuary ranged from -23.1 (autumn 1992) to $-22.5 \%$ (spring 1993) and its $\delta^{15} \mathrm{~N}$ was between 6.1 (winter 1993) and 6.5\% (summer 1992).

The average carbon isotopic composition of SOM (i.e. including benthic diatoms) ranged from -20.7 (spring 1993) to $-18.7 \%$ (winter 1993) and was not significantly different among the sampling periods (Kruskal-Wallis ANOVA, $\mathrm{p}>0.3$ ). The corresponding $\delta^{15} \mathrm{~N}$ values, from 6.3 (winter 1992) to $6.6 \%$ (summer 1993), are similar to results reported for other coastal surficial sediments (Couch 1989, Currin et al. 1995).

Average carbon isotopic ratios of nematodes ranged from -16.4 (summer 1992) to $-15.3 \%$ (spring 1993) for the total sampling period (mean value $-15.9 \%$ ). They were not significantly different among the periods of harvest (Kruskall-Wallis ANOVA, $p>0.25$ ). Corresponding $\delta^{15} \mathrm{~N}$ values ranged from 8.9 (summer 1992) to $9.3 \%$ (autumn 1992), with a mean value of $9.1 \%$, higher than the $5.3 \%$ reported by Couch (1989). $\delta^{15} \mathrm{~N}$ values were not significantly different among the sampling dates either (Kruskall-Wallis ANOVA, p > $0.25)$.

Discussion. The composition of the total SOM is highly heterogeneous. It includes both in situ primary producers (i.e. microphytobenthos and macroalgae) and detritus of varied origins. Suspended POM and SOM had very similar $\delta^{15} \mathrm{~N}$, but $\delta^{13} \mathrm{C}$ was heavier for SOM than for suspended POM. Microphytobenthos is the benthic component of SOM that causes enrichment (relative to POM) without significantly modifying the $\delta^{15} \mathrm{~N}$. Indeed, in the intertidal mudflats of the Marennes-Oléron Bay, a large part of the SOM corresponds to terrestrial materials brought by the Charente River (average $\delta^{13} \mathrm{C}$ of $-27.5 \%$ according to Riera \& Richard 1996). Another fraction of SOM comes from the sedimented estuarine phytoplankton, which is also depleted in ${ }^{13} \mathrm{C}$, with an average value of $-23.5 \%$ (Riera \& Richard 1996). Therefore, the SOM ${ }^{13} \mathrm{C}$ enrichment relative to suspended POM should come from the other enriched sources: the microphytobenthos and the macroalgae. Fucus biomass is strongly predominant at the sampling site; therefore, a significant contribution of Ulva and Enteromorpha to the SOM pool is unlikely. If Fucus was the main contributor to the $\delta^{13} \mathrm{C}$ enrichment of the SOM pool, then $\delta^{15} \mathrm{~N}$ should have been higher than the values measured. Thus, in the present study, benthic diatoms appear to be the main cause of the $\delta^{13} \mathrm{C}$ enrichment. However, some contribution of Fucus is likely to explain the balance in the $\delta^{15} \mathrm{~N}$ since the microphytobenthos is ${ }^{15} \mathrm{~N}$ depleted relative to SOM. Our isotopic measurements provide evidence of the importance of benthic diatoms in the total organic matter pool of the sediments on the intertidal mudflats in the Marennes-Oléron Bay, and we can therefore infer that the actual $\delta^{13} \mathrm{C}$ value of the detrital part of the SOM must be much more negative than the mean measured value (around $-19 \%$ ) for total SOM

It should, however, be stressed that this conclusion (as well as the remaining portions of the discussion) is based on the hypothesis that the isotopic ratios of macroalgal detritus are close to those of the corresponding living algae. The change in the isotopic composition sometimes observed during the degradation of some plants, such as Spartina (Currin et al. 1995), is generally ascribed to their high content of lignin, which is very ${ }^{13} \mathrm{C}$-depleted (Benner et al. 1987) and which affects nitrogen availability (Benner et al. 1984). However, from the results reported by Spies et al. (1989) for Macrocystis pyrifera and by Stephenson et al. (1986) for Laminaria longicruris it is likely that the carbon isotopic ratios of living and detrital macroalgae are not significantly different because macroalgae generally lack a refractory component ( $R$. Benner pers. comm.). There have been no studies assessing changes in $\delta^{15} \mathrm{~N}$ of degrading macroalgal detritus.

For each sampling date there is a large difference between nematodes and SOM $\delta^{13} \mathrm{C}$ (Fig. 2). These differences range between 2.5 (winter 1993) and $5.4 \%$ (spring 1993). They are much too large to be explained only by the metabolic enrichment in ${ }^{13} \mathrm{C}$, which is close to $1 \%$ and occurs during the assimilation of food (DeNiro \& Epstein 1978, Rau et al. 1983). This enrichment indicates that nematodes preferentially utilize one or several specific (and ${ }^{13} \mathrm{C}$-enriched) components of the SOM pool.

There are at least 2 main difficulties in the interpretation of stable isotope data in terms of trophic transfers. The first one is caused by possible overlap of the isotopic values of different potential food sources. This drawback 


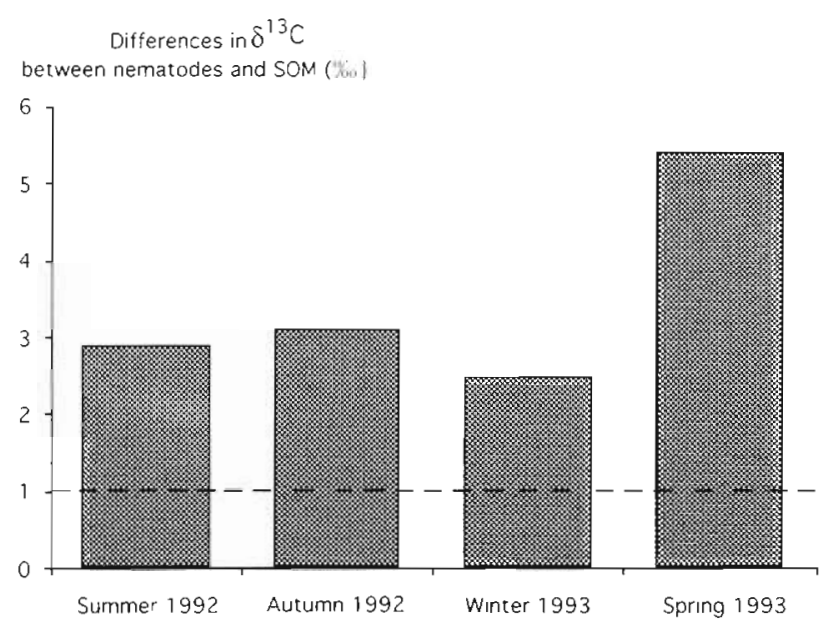

Fig. 2. Temporal changes in the mean carbon isotopic differences between nematodes and sedimented particulate organic matter (SOM) within the top $\mathrm{cm}$ of sediment. (---) Average carbon trophic enrichment

is especially important for ${ }^{15} \mathrm{~N}$ in estuarine environments (Fry \& Sherr 1984, Couch 1989). However, in the present study, it appears that the coupling of $\delta^{13} \mathrm{C}$ and $\delta^{15} \mathrm{~N}$ values results in a clear bidimensional separation of the different potential food sources (Fig. 3).

The second difficulty lies in the fact that the isotopic composition of consumers can either reflect the exploitation of a single food source or the bal-

ance between the utilization of several sources. The mean isatopic composition of nematode diet can be estimated from the isotopic composition of the nematodes themselves, taking into account the enrichment occurring during assimilation of food (Fig. 3). This expected enrichment, close to $1 \%$ for carbon (DeNiro \& Epstein 1978, Rau et al. 1983) and between 3 and $4 \%$ for nitrogen (DeNiro \& Epstein 1981, Rau et al. 1983, Owens 1987), is shown by the dashed line of Fig. 3 starting from the average $\mathrm{C}$ and $\mathrm{N}$ isotopic values of nematodes recorded for all the dates of harvest (because there was no significant effect of the dates of harvest on either of these data). According to this procedure, the expected $\delta^{13} \mathrm{C}$ and $\delta^{15} \mathrm{~N}$ of the preferentially exploited food resource would be -16.9 and $5.6 \%$, respectively. These values are very similar to the isotopic ratios of microphytobenthos, and point to benthic diatoms if we assume a unique food source in the nematode diet. No other single food source could so strongly match these theoretical values: all the macroalgae are too ${ }^{11} \mathrm{~N}$-enriched, while POM and the detrital part of SOM are too ${ }^{13} \mathrm{C}$ depleted
Different mixtures of food sources could also explain the isotopic composition of nematodes. Because SOM is a mixture of the other sources, we have only considered the 3 main sources: the macroalga Fucus (dominant at the sampling site), POM (in which phytoplankton and terrestrial detritus cannot be discriminated), and the microphytobenthos. The limits of the proportions of these mixtures have been drawn on Fig. 3. The closer the theoretical value of a nematode food resource is to the value of a pure food source, the higher the proportion of that source in the diet of the consumer is, if we exclude the possibility that assimilated carbon and nitrogen are from different origins (then carbon is mostly derived from Fucus and nitrogen originates from POM). This is rather unlikely because macroalgal detritus contains relatively high amounts of nitrogen that can be readily assimilated by primary consumers (Findlay \& Tenore 1982), thus shifting the nitrogen isotopic composition towards higher values than the theoretical ones.

Our overall conclusion is that nematodes living on the intertidal mudflat of the Marennes-Oléron Bay derive most of their feeding requirements from microphytobenthos.

This result, which reflects assimilation, is in good agreement with previous data assessing the ingestion of microphytobenthos (mostly diatoms) by epibenthic

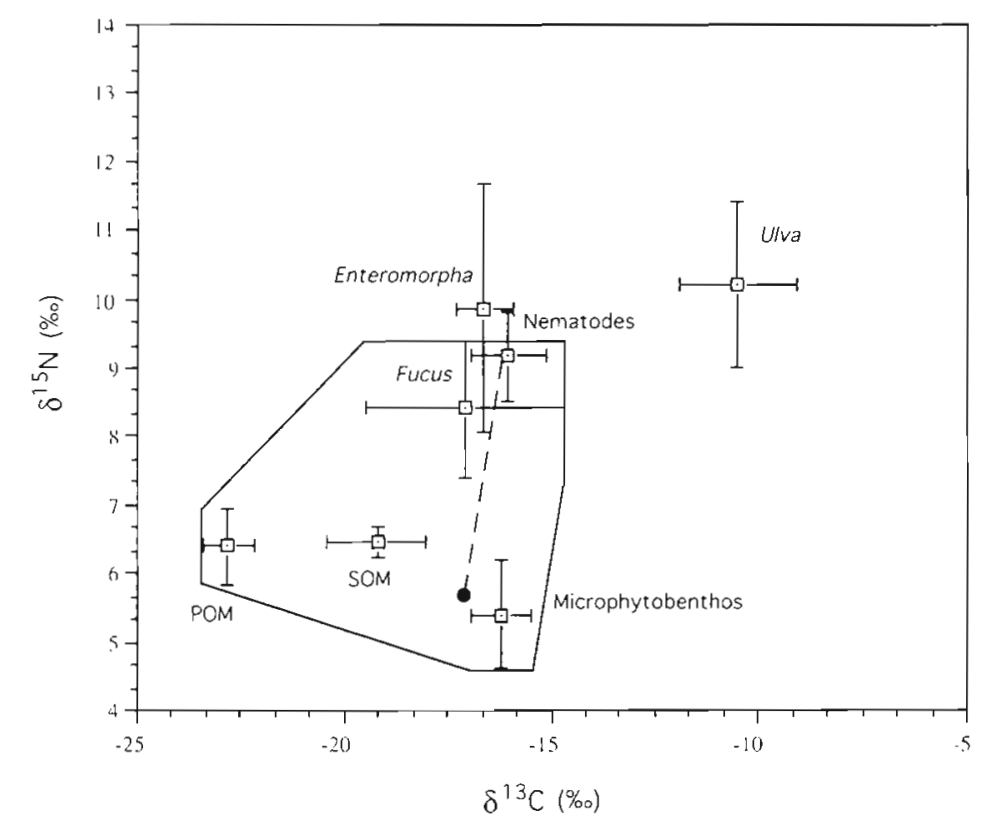

Fig. 3. Plot of mean $\delta^{13} \mathrm{C}$ and $\delta^{1} \mathrm{~N}$ (over the total sampling period) of both nematodes and their potential food sources. Vertical and horizontal bars correspond to standard deviations. Average $\delta^{13} \mathrm{C}$ and $\delta^{15} \mathrm{~N}$ values corresponding to the theoretical food source of nematodes taking into account the trophic enrichment. (-- ) Trophic shift in carbon and nitrogen 
nematodes (Montagna 1984 and Montagna et al. 1995 for the intertidal mudflat considered in this study). On the other hand, Couch (1989), using stable isotope analysis, suggested that, on the southeast coast of the United States, detritus derived from Spartina alterniflora may be predominant in the diet of meiofauna relative to benthic diatoms when seasonal conditions allow for an accumulation of detrital Spartina and for the development of the associated microbial biomass. Although her data interpretation was complicated by the proximity of the isotopic signatures of several food sources (especially Spartina detritus and diatoms), one of the major conclusions of Couch's study was that microphytobenthos cannot constitute the sole food source of both nematodes and harpacticoid copepods. The absence of phanerogams, and the scarcity of macroalgae in our study area help to pinpoint the importance of microphytobenthos as the main food resource for nematodes in Marennes-Oléron Bay. However, the present study is based on an average nematode number which probably includes different feeding guilds in accordance with Weiser's classification (1953). Our results suggest that diatom feeders dominate within the nematode community. Complementary studies may be necessary to measure the proportions of the different feeding guilds and to determine if their temporal variations are consistent with variations of benthic diatom standing stock in this intertidal mudflat. Obviously communities of nematodes living under different ecological conditions will have different feeding habits.

Nematodes generally have much higher turnover rates than macrofauna (Gerlach 1971) and represent one of the main food sources for many predators, such as fish and shrimp (Bell \& Coull 1978). Therefore the results of this study support the hypothesis of the key role of the close trophic link between microphytobenthos and nematodes in the transfer of organic matter towards higher trophic levels in muddy intertidal environments.

Acknowledgements. This work was supported by the PoitouCharente's Region through the GIS Marennes-Oléron Programme. P. Riera received financial support from IFREMER. The authors are grateful to P. A. Montagna for his reading of and useful comments on the manuscript. The comments from 3 anonymous referees also greatly helped to improve the manuscript.

\section{LITERATURE CITED}

Bell SS, Coull BC (1978) Field evidence that shrimp regulates meiofauna. Oecologia 35:141-148

Benner R, Fogel ML, Sprague EK, Hodson RE (1987) Depletion of ${ }^{13} \mathrm{C}$ in lignin and its implications for stable carbon isotope studies. Nature 329:708-710

Benner R, Maccubin AE, Hodson RE (1984) Preparation, chạr- acterization and microbial degradation of specifically radiolabelled $\left[{ }^{14} \mathrm{Cl}\right.$ lignocelluloses from marine and freshwater macrophytes. Appl Environ Microbiol 47:381-389

Boutton TW (1991) Stable carbon isotope ratios of natural materials: I. Sample preparation and mass spectrometric analysis. In: Coleman DC, Fry B (eds) Carbon isotope techniques. Academic Press, San Diego, p 155-171

Brown TJ, Sibert JR (1977) Food of some harpacticoid copepods. J Fish Res Bd Can 34:1028-1031

Callens (1994) Mise au point d'une procédure de cartographie des stocks annuellement exploitables en Fucales; exemples de deux sites: Pleubian-Bréhat (Côtes d'Armor) et île d'Oléron-île de Ré (Charente maritime). PhD thesis, Ecole Nationale Supérieure Agronomique de Rennes

Canou-Le Gall V, Blanchard GF (1995) Monthly measurements of pigment concentration from an intertidal muddy sediment of Marennes-Oléron Bay, France. Mar Ecol Prog Ser 121:171-179

Colijn $F_{1}$ de Jonge VN (1984) Primary production of microphytobenthos in the Ems-Dollard Estuary. Mar Ecol Prog Ser 14:185-1.96

Couch CA (1988) A procedure for extracting large numbers of debris-free, living nematodes from muddy marine sediments. Trans Amer Microsc Soc 107:96-100

Couch CA (1989) Carbon and nitrogen stable isotopes of meiobenthos and their food resources. Estuar Coast Shelf Sci $28: 433-441$.

Coull BC, Bell SS (1979) Perspectives in meiofaunal ecology In: Livingston RJ (ed) Ecological processes in coastal and marine systems. Plenum Press, New York, p 189-216

Creach V (1995) Origine et transferts de la matière organique dans un marais littoral: utilisation des compositions isotopiques naturelles du carbone et de I'azote. PhD thesis, Univ Rennes I

Currin CA, Newell SY, Paerl HW (1995) The role of standing dead Spartina alterniflora and benthic microalgae in salt marsh food webs: considerations based on multiple stable isotope analysis. Mar Ecol Prog Ser 121:99-116

de Jonge VN, Bouwman LA (1977) A simple density separation technique for quantitative isolation of meiobenthos using colloidal silica Ludox-TM. Mar Biol 42:142-148

DeNiro MJ, Epstein S (1.978) Influence of diet on the distribution of carbon isotopes in animals. Geochim Cosmochim Acta 42:495-506

DeNiro MJ, Epstein S (1981) Influence of diet on the distribution of nitrogen isotopes in animals. Geochum Cosmochim Acta 45:341-351

Findlay S, Tenore K (1982) Nitrogen sources for a detritivore: detritus substrate versus associated microbes. Science 218:371 373

Fry B (1988) food web structure on George bank from stable C, $\mathrm{N}$, and $\mathrm{S}$ isotopic compositions. Limnol Oceanogr 3.3 $1182-1190$

Fry B, Sherr EB (1984) $\delta^{13} \mathrm{C}$ measurements as indicators of carbon flow in marine and freshwater ecosystems. Contnb Mar Sci 27:13-47

Gerlach SA (1971) On the importance of marine melofauna for benthos communities. Oecologla 6:169. 190

Gerlach SA (1978) Food-chain relationships in subtidal silty sand marine sediments and the role of meiofauna in stimulating bacterial productivity. Oecologia 33:55-69

Haines EB, Montague CL (1979) Food sources of estuanne invertebrates analysed using ${ }^{13} \mathrm{C} /{ }^{12} \mathrm{C}$ ratios. Ecology 60 : $48-56$

Heip C, Smol N, Hautekeit W (1974) A rapid method for extracting nematodes and copepods from mud and detritus. Mar Biol 28:79-81 
Incze LS, Mayer LM, Sherr EB, Macko SA (1982) Carbon inputs to bivalve mollusks: a comparison of two estuaries. Can J Fish Aquat Sci 39:1348-1352

Mariotti A (1982) Apports de la géochimie isotopique à la connaissance du cycle de l'azote. Thesis, Etat Sci, Paris 6

Montagna PA (1984) in situ measurement of meiobenthic grazing rates on sediment bacteria and edaphic diatoms. Mar Ecol Prog Ser 18:119-130

Montagna PA (1995) Rates of meiofaunal microbivory: a review. Vie Milieu 45:1-10

Montagna PA, Bauer JE (1988) Partitioning radiolabeled thymidine uptake by bacteria and meiofauna using metabolic blocks and poisons in benthic feeding studies. Mar Biol 98:101-110

Montagna PA, Blanchard GF, Dinet A (1995) Effect of production and biomass of intertidal microphytobenthos on meiofaunal grazing rates. J Exp Mar Biol Ecol 185:149-165

Montagna PA, Yoon WB (1991) The effect of freshwater inflow on meiofaunal consumption of sediment bacteria and microphytobenthos in San Antonio Bay, Texas. Estuar Coast Shelf Sci 33:529-547

Owens NJP (1987) Natural variations in ${ }^{15} \mathrm{~N}$ in the marine environment. In: Blaxter JHS, Southward AJ (eds) Advances in marine biology, Vol 24. Academic Press, London, p 389-451

Rau GH, Mearns AJ, Young DR, Olson RJ, Schafer HA, Kaplan IR (1983) Animal $\delta^{13} \mathrm{C}$ correlates with trophic level

This note was presented by K. R. Tenore (Senior Editorial Advisor), Solomons, Maryland, USA in pelagic food webs. Ecology 64:1314-1318

Ravail-Legrand B (1993) Incidences du débit de la Charente sur la capacité biotique du bassin ostréicole de MarennesOléron. PhD thesis, Univ Nantes

Riera P (1995) Origine et devenir de la matière organique dans un écosystème estuarien à vocation conchylicole. Utilisation du traçage isotopique naturel. PhD thesis, Univ Bordeaux I

Riera P, Richard P (1996) Isotopic determination of food sources of Crassostrea gigas along a trophic gradient in the estuarine bay of Marennes-Oléron. Estuar Coast Shelf Sci 42:347-360

Schwinghamer P, Tan FC, Gordon DC (1983) Stable carbon isotope studies on the pecks cove mudflat ecosystem in the Cumberland basin, Bay of Fundy. Can J Fish Aquat Sci 40 (Suppl 1):262-273

Spies RB, Bauer JE, Hardin D (1989) Stable isotope study of sedimentary carbon utilization by Capitella spp.: effects of two carbon sources and geochemical conditions during their diagenesis. Mar Biol 101:69-74

Stephenson RL, Tan FC, Mann KH (1986) Use of stable carbon isotope ratios to compare plant material and potential consumers in a seagrass bed and a kelp in Nova Scotia Canada. Mar Ecol Prog Ser 30:1-7

Weiser W (1953) Die Beziehung zwischen Mundhöhlengestalt, Ernährungsweise und Vorkommen bei freilebenden marinen Nematoden. Ark Zool 4:439-484

Manuscript first received: February 10, 1996

Revised version accepted: July 4, 1996 